\title{
Management of Gunshot Injury of Glans Penis that Extends to Anterior Urethra: A Rare Case Report
}

\section{Anterior Üretraya Uzanım Gösteren Glans Penis Ateşli Silah Yaralanması: Nadir Bir Olgu Sunumu}

\author{
Özkan Onuk*, Burak Arslan*, Fatih Yanaral, Aydın İsmet Hazar*, Arif Özkan*, \\ Tuğrul Cem Gezmiş*, Barış Nuhoğlu* \\ Haseki Training and Research Hospital, Clinic of Urology, Istanbul, Turkey \\ *Taksim Training and Research Hospital, Clinic of Urology, Istanbul, Turkey
}

\section{Abstract}

Penetrating genital injuries are seen infrequently and most cases are associated with multiple organ trauma. Other rare isolated lesions could occur with gunshot wounds, human or animal bites, and selfmutilation. In this paper, we present a rare case of penile gunshot wound and highlight the optimal management of the patient.

Keywords: Genital trauma, gunshot wound, penile injury
Penetran genital yaralanmalar nadir görülürler ve çoğu durumda çoklu organ travması ile ilişkilidirler. Diğer nadir izole lezyonlar ateşli silah yaralanmaları, insan veya hayvan ısırıkları ve hastanın kendisini yaralaması ile meydana gelebilir. Bu yazıdaki amacımız, penil kurşun yarası olan nadir bir olguya en uygun yaklaşımı irdelemektir.

Anahtar Sözcükler: Genital travma, ateşli silah yarası, penil yaralanma

\section{Introduction}

External genital injuries, including penetrating or blunt injuries, burn, amputation, and fracture injuries account for $33-66 \%$ of all urological injuries (1). Penile fracture caused by inflection of the erect penis during sexual intercourse, and testicular rupture caused by blunt scrotal trauma are the most common types of genital injuries $(2,3)$. Penetrating genital injuries are seen infrequently and most cases are associated with multiple organ trauma $(4,5)$. Other rare isolated lesions could occur with gunshot wounds, human or animal bites, and self-mutilation due to the psychological reasons $(6,7)$. The extent of penetrating injury may vary from mild to severe, depending on its location and whether it involves the cavernosal body, urethra or penile cutaneous tissue alone. In an effort to assess and manage penile injuries adequately, a penile injury severity scale was published by the American Association for the Surgery of Trauma (8). Cutaneous and Buck's fascia (corpus cavernosum) lacerations are classified as grade 1 and 2, a cutaneous avulsion/laceration through glans/ meatus/cavernosum or urethral defect $<2 \mathrm{~cm}$ is classified as grade 3, partial and total penectomy are classified as grade 4 and 5, respectively. The aim of our report was to present a rare case of a penile gunshot wound and highlight the optimal management of the patient.

\section{Case}

A 56-year-old male patient was admitted to the emergency department at our hospital with penetrating gunshot injury to the penis. During the physical examination, two bullet signs were seen on the glans penis. The entrance of the bullet was located on the left side and its exit was located at the opposite of the entrance, on the right side of the glans penis (Figure 1). There was a noticeable defect at glandular urethra with minimal tissue loss and the cavernous bodies of penis were intact. Retrograde urethrogram was performed before urethral
Address for Correspondence/Yazısma Adresi: Burak Arslan Taksim Training and Research Hospital, Clinic of Urology, İstanbul, Turkey Phone: +90 5336599889 E-mail: drbarslan@yahoo.com

Received/Geliş Tarihi: 15 February 2016 Accepted/Kabul Tarihi: 20 March 2016
${ }^{\circ}$ Copyright 2016 by The Medical Bulletin of Haseki Training and Research Hospital The Medical Bulletin of Haseki published by Galenos Yayınevi. ๑Telif Hakkı 2016 Haseki Eğitim ve Araştırma Hastanesi Haseki Tıp Bülteni, Galenos Yayınevi tarafından basıımışır. 
catheterization and no extravasation was seen except fossa navicularis. Antibiotic prophylaxis (ceftriaxone $1 \mathrm{gr}$ and metronidazole $500 \mathrm{mg}$ ) was performed for an hour before the operation. Devitalised tissue due to the thermal impact of the bullet was debrided. Fossa navicularis and lesions on glans penis were repaired with primary closure using absorbable sutures. An $18 \mathrm{Fr}$ silicone urethral Foley catheter was placed after the reconstruction (Figure 2). Broad spectrum antibiotic was given orally for a week. The urethral catheter was removed 7 days after surgery and the patient was discharged. Due to occurrence of meatal

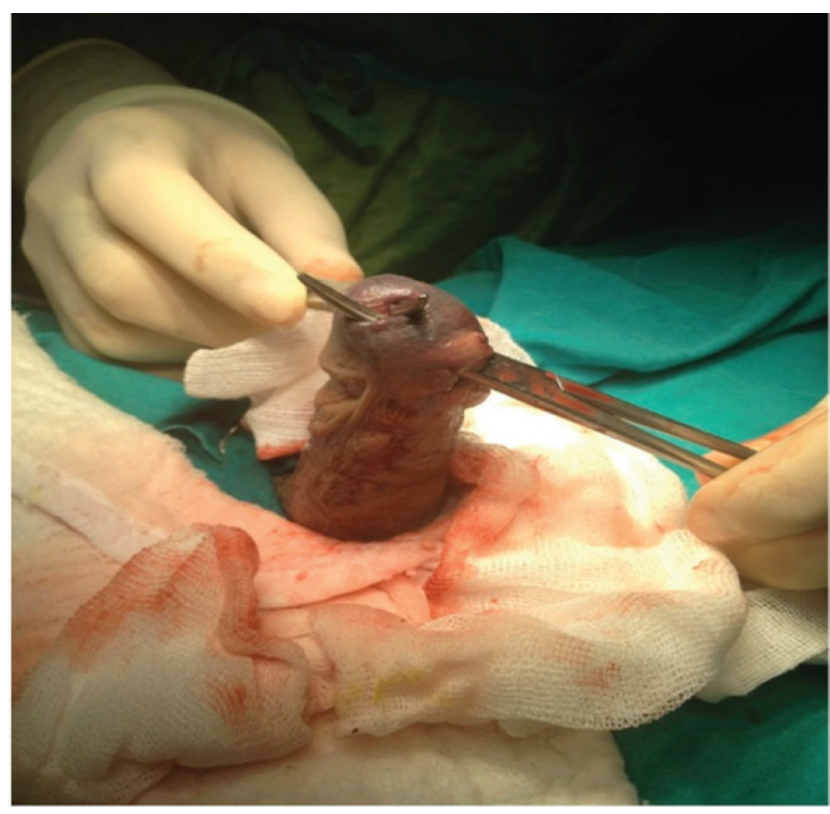

Figure 1. Bullet signs on the glans penis

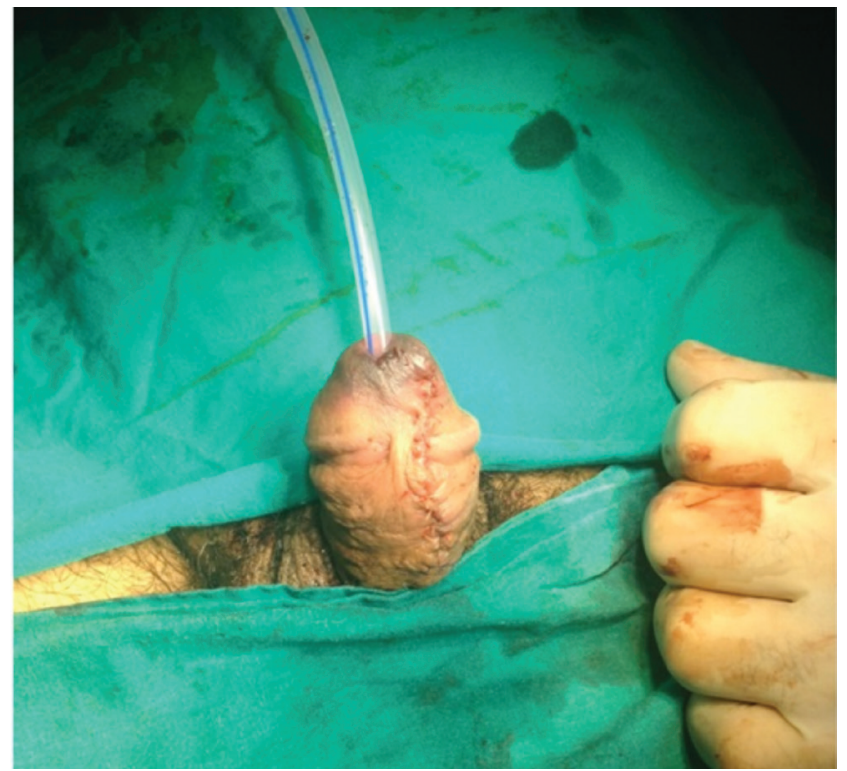

Figure 2. The glans penis after reconstruction stenosis during the follow-up, meatotomy was performed. One month after the intervention, the micturition pattern was normalized and the surgical wound was completely healed.

\section{Discussion}

Since the majority of patients with penile injuries do not seek medical treatment due to social embarrassment, the real incidence is underreported (9). If hospital admission is delayed after a penile injury, the risk of complications, such as penile curvature, erectile dysfunction and loss of tissue, increases. Krishna Reddy et al. (10) evaluated 156 cases of male external genitalia injuries and reported that early surgical treatment led to restoration of penile function without serious complications especially in penile fracture.

Primary assessment includes a clinical history and physical examination. Ultrasound can be used to assess the extent of damage or to exclude. A study conducted by Cavalcanti et al. (11) retrospectively assessed 43 patients with penile lesions from gunshot wounds in Brazil. Fortyone patients underwent surgical exploration on the basis of physical examination and the surgeons noticed that four (9.5\%) patients had superficial lesion. Consequently, these four patients were operated although they could be managed nonoperatively.

In cases with blood in the meatus or microscobic/ macroscobic hematuria in urinanalysis, retrograde urethrocystogram should be done to exclude urethral damage (12). According to the literature, penetrating penile injuries may be associated with concomitant urethral injuries in $11-29 \%$ of cases $(3,13)$. Primary closure, end-to-end anastomosis and autologous or xenograft are the treatment options according to the extension of the damage. Particularly in our case, the patient had a lesion on fossa navicularis only, thus, we were convinced that primary closure was sufficient. Since post-operative complications including wound infection and stricture have been reported in 9\% of cases, the management should include antibiotics due to risk of infection, and an urethral catheter for reconstruction (14). In the present case, a meatal stenosis emerged in early postoperative period and was treated surgically under local anesthesia. Evaluation and management of gunshot wounds to the penis may be complex. Retrograde urethrogram should be performed in all cases except for insignificant and superficial wounds. Penile lesions from gunshot wounds should be treated with immediate surgical intervention. In exceptional situations featuring superficial lesions only, conservative treatment may be applied. 


\section{Ethics}

Peer-review: Internally peer-reviewed.

\section{Authorship Contributions}

Concept: Burak Arslan, Fatih Yanaral, Barış Nuhoğlu. Design: Burak Arslan, Fatih Yanaral, Özkan Onuk, Aydın Ismet Hazar. Data Collection or Processing: Burak Arslan, Fatih Yanaral, Özkan Onuk. Analysis or Interpretation: Burak Arslan, Fatih Yanaral, Özkan Onuk. Literature Search: Arif Özkan, Tuğrul Cem Gezmiş. Writing: Burak Arslan, Özkan Onuk.

Conflict of Interest: No conflict of interest was declared by the authors.

Financial Disclosure: The authors declared that this study received no financial support.

\section{References}

1. Brandes SB, Buckman RF, Chelsky MJ, et al. External genitali aguns hot wounds: a ten-yearexperience- withfifty-sixcases. J Trauma 1995;39:266-71.

2. Morey $A F$, Brandes $S$, Dugi $D D$, et al. Urotrauma: AUA guideline. J Urol 2014;192:327-35.

3. Cass AS, Luxenberg M. Testicular injuries. Urology 1991;37:528-30.
4. Tiguert R, Harb JF, Hurley PM, et al. Management of shotgun injuries to the pelvis and lower genitourinary system. Urology 2000;55:193-7.

5. Phonsombat S, Master VA, McAninch JW. Penetrating external genital trauma: a 30-year single institution experience. J Urol 2008; 180:192-5.

6. Gomez RG, Castanheira AC, McAninch JW. Gunshot wounds to the male external genitalia. J Urol 1993;150:1147-9.

7. Jezior JR, Brady JD, Schlossberg SM. Management of penile amputation injuries. World J Surg 2001;25:1602-9.

8. Mohr AM, Pham AM, Lavery RF, et al. Management of trauma to the male external genitalia: the usefulness of American Association for the Surgery of Trauma organ injury scales. J Urol 2003;170:2311-5.

9. Eke N. Fracture of the penis. Br J Surg 2002;89:555-65.

10. Krishna Reddy SV, Shaik AB, Sreenivas K. Penile injuries: A 10year experience. Can Urol Assoc J 2014;8:E626-31.

11. Cavalcanti AG, Krambeck $R$, Araujo $A$, et al. Penile lesion from gunshot wound: a 43-case experience. Int Braz J Urol 2006;32:56-60.

12. Summerton DJ, Djakovic N, Kitrey ND. Guidelines on urologictrauma. EAU Guideline 2015.

13. Cline KJ, Mata JA, Venable DD, et al. Penetrating trauma to the male external genitalia. J Trauma 1998;44:492-4

14. Orvis BR, McAninch JW. Penile rupture. Urol Clin North Am 1989;16:369-75. 